Faez Saad Al-Shihri, Principles of sustainable development and their application in urban planning in saudi arabia, pp.1703-1727

\title{
PRINCIPLES OF SUSTAINABLE DEVELOPMENT AND THEIR APPLICATION IN URBAN PLANNING IN SAUDI ARABIA
}

\author{
Faez Saad Al-Shihri \\ Dept. of Urban \& Regional Planning, College of Architecture and Planning, \\ University of Dammam P.O Box 2397 Dammam 31451 Saudi Arabia
}

Received 16 April 2013, accepted 1 July 2013

\begin{abstract}
Urban planning can play a very important role in achieving sustainable growth and development by integrating 'sustainable development principles' in urban planning strategies, policies, programs and projects. There are diverse conceptualization and understanding regarding sustainability, and there is still no single format of integrating the principles of sustainability into a cohesive and integrated urban planning methodology. Various agencies and institutions have articulated the concepts and principles of sustainability at various levels and with a variety of depth and details.

Based on the literature review this paper studies the emergence of the concept of sustainability, its dimensions and under-pining, and how urban planning practitioners and institutions have attempted to integrate the basic principles into their practices. The objective is to examine to what extent the government in the Kingdom of Saudi Arabia and its development agencies have internalized the prevailing notion of sustainability and the principles that entail the concept, particularly how the principles are embedded in development Planning strategies and policies.

This paper consists of introduction and three parts: After the introduction, the Part One presents a selective review of the emergence and spread of the concept of sustainability to integrate the substantive principles in the planning practice. It discusses the application of sustainability principles in relation to urban development and planning in general. Then it summarizes some guidelines and related action programs provided by leading professional institutions in urban planning. The literature review part concluded with sustainability assessment criteria. Part Two outlines the institutional developments and national policies and commitments in the kingdom of Saudi Arabia in respect of sustainable development as stated in the 8th and 9th National Development Plans, National Spatial Strategy, and General Environmental Law. The review of Saudi experience concludes with an assessment summary showing to what extent sustainability principles have been incorporated in Saudi Arabian development planning strategies. Part Three concludes that Saudi Arabia has incorporated most of the major sustainable development principles extracted from the literature review. It highlights policies and programs for implementing the principles at regional and local levels by various urban development actors (the communities, public agencies, private firms and academia) and sectors such as housing, transportation and infrastructure, urban services, industrial and commercial land uses, etc. would go a long way in achieving sustainable urban development in Saudi Arabia.

The paper is based primarily on the literature review and secondary data collected through a review of some previous studies, books, articles and local and international reports on the subject, including the basic terms and concepts as well as some important international experiences in sustainable development and urban planning.
\end{abstract}

Keywords: Development, Sustainable Development, Environment, Pollution, Energy use, Land use, Urban Planning, Strategy, Policy, Action.

Corresponding author.

E-mail: fshihri@ud.edu.sa 


\section{Introduction}

Over the last two decades the twin word 'sustainable development' has become a popular catch phrase. Planners, particularly urban planners are increasingly showing earnestness to infuse their work with the globally expressed concern for sustainability in the process of growth and development. In fact the emergence of environmental movement has brought the concern for sustainability in the forefront of development strategies and policies. However, up-to-date there is no commonly agreed formula nor clearly spelled out principles to integrate the goals in sustainability into urban planning practice. There is diversity and complexity in understanding and interpretation of the concept and principles, and as such a uniform practice of sustainable urban planning based on consensus is yet to evolve.

\section{Sustainability: a literature review}

This part includes a review worldwide practice of sustainability in development planning as presented in previous studies. It highlights the basic concepts of sustainable development; its main principles, its various strategies, its strategic goals and the actions taken to achieve them. The part is concluded with a summary of the basic principles of sustainability that could be used as criteria to assess the level of sustainability in any development planning functions. These principles should be incorporated in any country's policies, program and plans to be considered sustainable urban developments.

\section{1. Concepts in sustainable development planning}

This section provides a limited review of basic issues on 'sustainability' and the popular concepts currently being thrown around, namely: what is sustainable development, what are the dimensions of sustainable development, criteria to be used in assessing sustainable urban development, the emerging new ideologies in urban planning e.g. new urbanism, what are the best practices in sustainable urban development so far, what are the policies and strategies advocated by prominent professional bodies e.g. American Planning Association (APA)in respect of land use, infrastructure, transportation, utilities, housing, social facilities, and overall urban growth management.

\section{1. 1. What is sustainable development?}

Over the last two centuries economic growth and the advancements in science and technology have raised the level of human consumption. World populations now demand more and better products of a wider variety more frequently and in greater quantities. At the same time world population has grown at an exponential rate. As a result, nonrenewable natural resources are being depleted, and as a result the environment is being degraded in an alarming manner and scale. This has raised concerns about the future of human civilization.

In the face of growing concern, the United Nations (UN) General Assembly held a conference in June 1972 in Stockholm that came up with some guiding principles regarding the care and stewardship of world environment. It affirmed that environmental quality is a fundamental human right and emphasized a global responsibility towards protecting the environment for future generations. In 1983, the World Commission on

Journal of Engineering Sciences, Assiut University, Faculty of Engineering, Vol. 41, No. 4, July, 2013,E-mail address: jes@aun.edu.eg 
Faez Saad Al-Shihri, Principles of sustainable development and their application in urban planning in saudi arabia, pp. 1703- 1727

Environment and Development was created, which has played a vital role in promoting the concept of sustainable development. The Commission (popularly known as the Brundtland Commission) described sustainable development as "development that meets the needs of the present without compromising the ability of future generations to meet their own needs."'[1]

Sustainable development has since emerged as a major goal in all global conferences and national development plans. The World Summit on Sustainable Development (WSSD), held in Johannesburg in 2002, set out the actions necessary to achieve sustainability under the heading of "Changing Unsustainable Patterns of Consumption and Production."

Advocating for adoption of plans for sustainable development, the WSSD announced the following consensus [2]:

- Promote an integrated approach to policy-making at the national, regional and local levels in order to ensure sustainable development.

- Introduce systems to promote sustainable development which would include planning for land-use, infrastructure, public transport networks and systems ensuring safe, affordable rides, increasing energy efficiency, reducing pollution, reducing congestion, reducing adverse health effects and limiting urban sprawl.

Till date, 'sustainable development' as a concept has received significant attention from individual academics and institutions. Nevertheless, the field is still far from being unambiguous [3]. There are over 70 different definitions of sustainability, as different academic fields and disciplines have their own definitions and approaches. Generic definitions of sustainable development too are being interpreted in many ways, whereas more specific definitions are found to be restrictive, reflecting the value judgments of the definer. This diversity is manifest on philosophical, political and operational levels. [2], [4]

Sustainable development has been defined by H. E. Daly from the view point of the depleting world resources, emphasizing the conservation of natural resources in the following words: "Development is sustainable if the rates of use of renewable resources do not exceed their rate of regeneration, the rates of use of non-renewable resources do not exceed the rate at which sustainable renewable substitutes are developed, and pollution rates do not exceed environment's assimilative capacity" [5]. This definition contains two defining characteristics of sustainability: (i)it asserts that the rates of consumption of renewable resources must not exceed the rate of their regeneration, implying prudent use of natural resources, and (ii) the second characteristic implies pollution caused by human activities must be controlled to remain within the corrective capacity of nature. This further implies that natural resources should be viewed not only as something to be consumed, but also as something that benefit us even when they are not consumed. In other words, our well-being is threatened when there are not enough of those resources around. [6], [7], [8].

\section{1. 2. Three E's of sustainable development}

The World Commission on Environment and Development (1987) postulates that "sustainable development strategy aims at promoting harmony among human beings and between humanity and nature." Sustainability concept implies that development be viewed from a societal and an environmental perspective. Sustainability, therefore, requires harmony between economic sustainability, social sustainability and environmental sustainability [9]. Also, sustainable development warrants a combined focus on three areas: People, Planet and Profit. From a development point of view this can be paraphrased as

Journal of Engineering Sciences, Assiut University, Faculty of Engineering, Vol. 41, No. 4, July, 2013,E-mail address: jes@aun.edu.eg 
Faez Saad Al-Shihri, Principles of sustainable development and their application in urban planning in saudi arabia, pp. 1703- 1727

People, Planet and Progress. In order to be sustainable, development should signify quality of life for all sections of society (people) and minimal disruption of the environment (planet), as well as economic growth (progress) [10]. The triple-P have been alternatively described as the three E's - Environment, Economy, and Equity [11].

Sustainable Development concept clearly warrants that the process of development must be environmentally bearable, economically viable, and socially equitable.

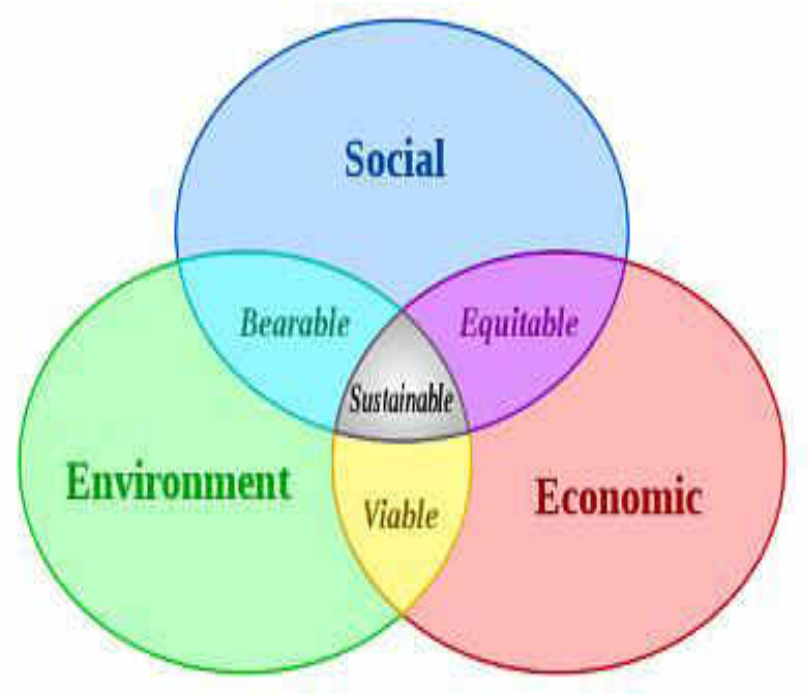

Figure1. The triple-E concept of sustainability

\section{1. 3. Some basic principles on sustainable development planning}

In the US, the President's Council for Sustainable Development (PSCD, 1997) has mandated a number of basic principles that decision maker sought to follow to ensure sustainable development; they are as follows: [11]

- Use of long term horizon in planning - Sustainable development require the use of a long-term horizon for decision making in which society would pursue long-term aspirations rather than simply making short-term, reactive responses to problems. By keeping an eye out for the long-term, sustainable development should ensure that options for future generations are maintained if not improved.

- Considering interdependence of factors - Sustainable development should recognize the interdependence of economic, environmental, and social well-being. It should promote actions that expand economic opportunity, improve environmental quality, and increase social well-being all at the same time, never sacrificing one for another.

- Ensuring public participation - Sustainable development depends on decision making process that is inclusive, participatory, and transparent. The planning process for sustainable development must, therefore, ensure the input of the stakeholders who will be affected by development decisions.

Journal of Engineering Sciences, Assiut University, Faculty of Engineering, Vol. 41, No. 4, July, 2013,E-mail address: jes@aun.edu.eg 
Faez Saad Al-Shihri, Principles of sustainable development and their application in urban planning in saudi arabia, pp. 1703- 1727

- Promoting Equity - Sustainable development should promote equity between generations and among different groups in society. It must recognize the need for ensuring equality and fairness, and reduce disparities in access to benefits.

- Promoting proactive prevention - Sustainable development planning is anticipatory. It must, therefore, promote efforts to prevent problems as the first course of action.

In the year 2000, the American Planning Association came out with an unprecedented declaration of its own principles and policy guidelines on sustainable development. The APA points out that pattern of human development - physical, social, and economic affect sustainability at the local as well as the global level. In line with other world institutions, APA re-emphasizes that planning for sustainability requires a systematic, integrated approach that brings together environmental, economic and social goals in a single package. Through this declaration the APA boldly asserts that planning for sustainability must be based on the following principles:[12]

- Planning processes should ensure that planning decisions are made in a holistic and fully-informed manner involving all segments of the community, and that planning for sustainability promotes responsible development - not antidevelopment.

- Planning practices must be based on a future oriented vision which look beyond current needs and recognizes environmental limits to human development.

- Planners must invoke the ethic of stewardship encouraging individuals and organizations to take full responsibility for the economic, environmental, and social consequences of their actions, balancing individual needs and wants with nature and the public good.

- Planning of development projects must promote economic development by efficiently and equitably distributing resources and goods; minimizing, reusing and recycling waste; and protecting natural ecosystems.

- Plans must promote resilient, diverse, and self-sufficient local economies that meet the needs of residents and build on the unique characteristics of the community.

- Planners must ensure that the outcome of their proposals for local and regional development expand choices and opportunities for all including the needs of those that are disadvantaged.

- Planners' ultimate goal should be to create communities with a healthy economy, environment and social climate that function in harmony with natural ecosystems and other species and allow people to lead healthy, productive and enjoyable lives.

- A democratic process of planning is required to achieve the greatest common good for all segments of population, protect the health of the environment and assure future generations of the resources they will need to survive and progress.

- Planners must take leadership in drafting and implementation of local, regional and national policies that support sustainability, such as APA's Growing Smart statutes.

The APA emphatically reiterates that city and regional planning is integrally related to defining how, where, and when human development occurs, which affects resource use. Planners can therefore play a crucial role in improving the sustainability of communities and the resources that support them.

Journal of Engineering Sciences, Assiut University, Faculty of Engineering, Vol. 41, No. 4, July, 2013,E-mail address: jes@aun.edu.eg 
Faez Saad Al-Shihri, Principles of sustainable development and their application in urban planning in saudi arabia, pp. 1703- 1727

\section{2. Strategies for sustainable urban development}

There is a clear need to translate the principles enunciated above into strategies, policies and actions. Since cities and urbanized areas are the locus of human activities, it is in the urbanized areas where the maximum extent of conflict and confrontation between natural environment and man-made environment takes place; and it here that the most immediate attention is needed. Sustainable urban development specifically implies achieving a balance between the development of the urban areas and protection of the environment; and at the same time achieving equity in employment, shelter, basic services, social infrastructure and transportation in urban areas. In principle, sustainable urban development is the one that improves the long-term social and ecological health of cities and towns." [13] A city ,in order to be sustainable ought to be planned and organized so as to enable all its citizens to meet their needs and improve their well-being without damaging the natural world or endangering the living conditions of fellow citizens at present or in the future.[14]

Recently heads of governments of the world met again at the United Nations Conference on Sustainable Development in Rio de Janeiro in 2012. They recognized the urgency of setting a vision for sustainable cities, inclusive of "initiation of city planning through to revitalization of older cities and neighborhoods, adopting energy efficient programs in building management and developing sustainable, and locally appropriate transport systems." Also, the importance of mixed-use planning and of encouraging non-motorized mobility was recognized. The conference further noted that "sustainable urban planning benefits from the involvement of multiple stakeholders as well as from full use of information and gender-disaggregated data, including demographic trends, income distribution and informal settlements.'[15]

In short, urban development, in order to be sustainable, must be proactively planned with a long term vision where the needs of all the citizens will be met satisfactorily not only for the present but also for the future. The strategic dimensions of planning should include:

- Protection of the natural environment and the ecology ensuring clean air and water,

- Provision of basic health services, housing and environmental sanitation for all.

- Appropriate and quality education, adequate employment opportunities and income.

- Facilities for recreation and cultural growth.

- A system of democratic and participatory process of planning involving all segments of population.

Clearly, the strategic areas of focus necessary for ensuring sustainable urban development listed above are ecologically aware, economically more rational, and socially more responsive. And as such should be considered as a point of departure from what is currently being practiced in many countries.[16].

\section{3. Actions to achieve strategic goals in planning for urban sustainability}

In respect of actions to achieve sustainable urban development, APA has come out with a most comprehensive list of actions to be taken by planners at all levels - local, regional,

Journal of Engineering Sciences, Assiut University, Faculty of Engineering, Vol. 41, No. 4, July, 2013,E-mail address: jes@aun.edu.eg 
Faez Saad Al-Shihri, Principles of sustainable development and their application in urban planning in saudi arabia, pp. 1703- 1727

national, and international. Accordingly, the APA suggests the following sets of actions that planners can take in support of sustainability [12]:

2. 3. 1. Land use actions toward sustainability

- Guide and contain urban growth to existing developed areas, control urban expansion into outlying undeveloped areas and encroachment upon nature.

- Ensure compact development through an integration of community activity areas: housing, shops, workplaces, schools, parks, civic facilities etc. - within walking or bicycling distance.

- Undertake remediation and redevelopment of 'brown field' sites and other developed lands that suffer from environmental or other constraints.

- Promote human-scaled development that is pedestrian-friendly and oriented around public transit.

- Introduce home-based occupations and work that reduce the need to drive and/or commute.

- Promote regional and urban designs that respect the regional ecosystems and natural functions including local food production that reduces need for long-range transport of food.

\section{3. 2. Transportation actions toward sustainability}

- Reduce the need for vehicle trips and vehicle miles travelled through compact, infill development, and mixed use development

- Introduce use of alternatives to the drive-alone automobile e.g. car-pool, park-\&ride, and public transit etc.

- Introduce local street designs that promote pedestrian and bicycle use, enhance access between neighborhoods and to neighborhood-based commercial developments, and discourage use of cars.

- Provide affordable, efficient transportation alternatives for everyone, especially low income households, elders, and others who cannot or do not own private cars.

2. 3. 3. Housing and building actions toward sustainability

- Encourage community and housing developments that are socially cohesive, reduce isolation, foster community spirit, and sharing of resources.

- Create compact and clustered residential development, including reduced minimum lot sizes.

- Ensure housing that is affordable to a variety of income groups within the same community.

- Encourage a diversity of occupants in terms of age, social, and cultural groups.

- Choose location of housing areas near employment centers.

- Encourage use of regenerative energy including solar-oriented housing and neighborhood design

- Ensure use of building materials with low "embodied energy" which are also chemical-free and toxin-free.

- Introduce ways of waste reduction and recycling of waste materials as well as of promoting recycling by residents.

- Formulate and use landscape design standards that minimize the use of pesticides and herbicides.

Journal of Engineering Sciences, Assiut University, Faculty of Engineering, Vol. 41, No. 4, July, 2013,E-mail address: jes@aun.edu.eg 
Faez Saad Al-Shihri, Principles of sustainable development and their application in urban planning in saudi arabia, pp. 1703- 1727

2. 3. 4. Open space/recreation actions toward sustainability

- Create of systems of green spaces within and among communities.

- Provide recreational facilities within walking and bicycling distance by localizing distribution of facilities.

- Ensure use of local materials and native plants in facility design as well as in landscaping.

- Procure funding for urban gardens, community gardens, open space provision and acquisition.

- Ensure preservation of wilderness areas, wildlife habitats and bio-diversity of area ecosystems.

- Undertake restoration of damaged natural systems through regenerative design approaches.

- Introduce responsible water conservation measures and storm water management system, minimize environmentally destructive technologies in developing new water sources.

\section{3. 5. Infrastructure development Actions toward sustainability}

- Promote facilities that employ renewable energy sources, or reduce use of fossil fuel for their operations and transport needs.

- Apply Design approaches and regulatory systems that focus on pollution prevention, re-use and recycling.

- Ensure reduction or elimination of impervious paving materials

- Promote innovative greenhouse sewage treatment facilities to minimize or eliminate the use of chemicals.

- Introduce system for conserving, and reusing wastewater at neighborhood or community level, reducing the need for large, expensive collection systems and regional processing facilities.

- Ensure reduction or elimination of impervious paving materials

2. 3. 6. Growth management actions toward sustainability

- Maximize the use of existing transport systems; minimize the need for new road/highway construction.

- Formulate appropriate development and population growth policies linked to carrying capacity of natural systems and community facilities.

- Adopt settlement development patterns that respect natural systems such as watersheds and wildlife corridors.

- Formulate growth management policies that maintain diversity in local populations and economies.

2. 3. 7. Watershed planning/floodplain management actions toward sustainability

- Guide development away from floodplains.

- Guide development away from barrier beaches.

- Preserve or restore wetland areas along rivers for natural flood control.

- Ensure recharge of groundwater basins.

- Introduce flood control and storm water techniques that enhance and restore natural habitats.

Journal of Engineering Sciences, Assiut University, Faculty of Engineering, Vol. 41, No. 4, July, 2013,E-mail address: jes@aun.edu.eg 
Faez Saad Al-Shihri, Principles of sustainable development and their application in urban planning in saudi arabia, pp. 1703-1727

- Legislate for prevention of wetlands destruction and restoration of degraded wetlands.

\section{3. 8. Planning processes/educational actions toward sustainability}

- Encouraging and enabling people to use transport other than gasoline-powered vehicles

- Educating citizens and public servants about both short-and long-term risks associated with the use and disposal of hazardous materials

- Educational efforts to reduce levels of consumption and waste generation at the household and community levels.

- Integrally involving local community residents in setting the vision for and developing plans for their communities and regions.

- Establishing avenues for meaningful participation indecision-making for all citizens and in particular for historically disadvantaged people.

- Providing for equitable educational opportunities for all members of society.

- Undertaking retraining of displaced manpower in the short-term by a planned shift to a more sustainable economy.

\section{4. Notable policies on planning for sustainability}

The global institutional guidelines particularly those on actions put forward by the APA seem to have inspired many decision makers and developers across the world. However, in spite of the apparent commitment for working towards well-designed sustainable communities, the process through which designers, developers and related stakeholders can achieve it is not well understood [17]. Urban planning systems have changed very little in the past couple of decades and are often contributors to urban problems rather than tools for human and environmental improvement. [18]The contemporary practices aimed at achieving sustainability, though significant, often appear to be lopsided, disjointed, and lacking comprehensiveness. Notable focuses on planning for sustainability are listed below.

\section{4. 1. Planning process}

The need for the involvement of all the segments of population in the planning process is nowhere better spelled out than by the APAs declaration of their Chapter Delegate Assembly in the year 2000. [12]

Notable researchers have pointed out that sustainable development can only be achieved through a new planning process.[19] In this connection Rydin comments that "A process of urban planning that responds to the requirements of sustainable urban development is needed for the sake of sustainable cities. Left to themselves, market forces cannot deliver an adequate and sustainable living environment" [20].

\section{4. 2. Time perspective}

From a sustainability point of view, it is important that planning has a long-term perspective. A team of European researchers has suggested that even 25 years is inadequate to assess the full consequences of some of our current actions [21]. But long term plans also have their negative aspects: (a) uncertainty increases rapidly beyond a certain time period, rendering plans less effective, and (b)long-term plans tend to have less influence on actual policy, making the whole exercise somewhat abstract. To find a

Journal of Engineering Sciences, Assiut University, Faculty of Engineering, Vol. 41, No. 4, July, 2013,E-mail address: jes@aun.edu.eg 
Faez Saad Al-Shihri, Principles of sustainable development and their application in urban planning in saudi arabia, pp. 1703- 1727

balance between the diverging forces, the researchers recommended a plan period of 15 t0 20 years for combined land use and transport plans for cities. Shorter and medium-term plans can be then taken provided due account of the various forms of uncertainty is taken into consideration and care is taken to avoid very long-term damage.

\section{4. 3. Public participation}

The importance of involving the community in different stages of the planning process is now universally recognized. Public participation is also viewed as a mechanism of ensuring accountability. The popular argument is that public participation can be a means for the communities whereby public authorities can be held responsible and accountable for implementation of development programs. Public participation can also be deployed to ensure equitable allocation and distribution of resources.

In recent years public participation is seen as a vital part of addressing environmental problems and bringing about comprehensive sustainable development. In some countries public participation has become a central principle of public policy making. In the UK, for example, it is observed that all levels of government have started to build citizen and stakeholder engagement into their policy-making processes. [22]

It is also argued that public participation allows governments to adopt policies and enact laws that are relevant to communities and take into account their needs. In New Zealand, for example, numerous laws (e.g. health, local government, environmental management) require government officials to "consult" those affected and take their views into consideration when making decisions. A plan generated without a participatory approach would hardly be sustainable, making it difficult to attain the goals envisaged in the plan. Reporting about the experience from an empirical planning study, it has been pointed out that "community participation enabled meaningful intervention in the area of resource allocation (human, natural, economic and cultural) that are valued by the local communities and thus constituted a rational basis for the creation of proposed sustainable activities, generating employment and wealth, preserving natural values and promoting establishment of public space with greater social sensitivity and responsibility."[19]

In translating the principles of sustainable urban development into practical plans for sustainable cities, one group of planners have focused mainly on the environmental issues: limiting consumption of resources, including energy, on the one hand and reducing generation of waste and pollution on the other. Such considerations have led to movements such as New Urbanism, Smart Growth, and Transit Oriented Development (TOD) in the United States and Europe.

\section{4. 4. New urbanism, smart growth, transit oriented development (TOD)}

New urbanism attempts to re-introduce age-old principles of urbanism, such as diversity, street life, human scale, etc. [23]. The neighborhoods should accommodate diverse populations and have a variety of land uses. The city ought to be designed to facilitate pedestrian traffic and public transit. Public spaces should be easily accessible to all and the design of spaces should reflect the history, climate, ecology and traditional construction methods [24].

Smart growth is considered to be "a collection of land-use and development principles that aim to enhance quality of life, preserve the natural environment and save money over time. Smart growth principles ensure that growth is fiscally, environmentally and socially responsible and recognizes the connections between development and quality of life. Smart growth enhances and completes communities by placing priority on compact development through infill, redevelopment and green space protection." [25]

TOD aims to develop high-density, multi-purpose, walk-able neighborhoods, around hubs of mass transit, thus reducing the dependency on the car and burning of fossil fuel.

Journal of Engineering Sciences, Assiut University, Faculty of Engineering, Vol. 41, No. 4, July, 2013,E-mail address: jes@aun.edu.eg 
Faez Saad Al-Shihri, Principles of sustainable development and their application in urban planning in saudi arabia, pp. 1703- 1727

The principles and objectives of quality of life, diversity and accessibility-both residential and commercial, public spaces, forms of soft mobility, diversity of the functions creating constant activity and lively environment, proximity services etc. are emphasized.

\section{4. 5. Planning scale}

In order to steer towards a more sustainable form of development of our cities, one has to look beyond the city scale. It is likely to require an integrated, coordinated, and efficient regional urban planning policy. [26] Citing a number of recent reports, pointed out an increasing "awareness that sustainable and prosperous metro areas will require there form of local zoning and the fashioning of new regional cooperative frameworks" [26].

The layout, location and density of residential development will have implications on the level of trip demand and consequently the levels of energy consumed and pollution emitted. Traditional land use zoning concepts with residential areas that are free from any other land use apart from basic neighborhood facilities are now recognized as unsustainable. Instead, mixed land use where places of employment, shopping and leisure are in close proximity to homes reduces trip generation, especially if the layout of the area is compact with facilities for walking and cycling. [12]

An interesting case study of planning for a mixed residential development is provided by the plan for Tama New Town near Tokyo, Japan. [27] [*Please see notes on Tama New Town appended at the end of the paper].It is pertinent to note that there is a great deal of similarity in the fundamental principles and ideas used in the planning of the Tama New Town and those advocated by the American Planning Association.

\section{4. 6. Sustainable urban transport}

Much of the woes that afflict modern cities and threaten their sustainability can be attributed to transport systems in place. A sustainable urban transport and land use system should reflect the following considerations [28]:

- provides efficient access to goods and services for all inhabitants of the urban area,

- protects the environment, cultural heritage and ecosystems for the present generation,

- Does not endanger the opportunities of future generations to reach at least the same welfare level as those living now, including the welfare they derive from their natural environment and cultural heritage.

- These considerations may be reflected in a number of thematic areas [29]:

- Linking transport planning and land use planning to reduce motorized trips[**Please see the notes appended at the end of the paper]

- Managing car traffic demand in other ways,

- Developing non-motorized transport infrastructure such as bicycle lanes,

- Encouraging the provision and use of public transport services, and

- Improving vehicle and fuel technologies and efficiency.

To attain the goals of sustainable transport various design standards are being applied at different spatial levels: local, urban, regional and national levels [29]:

- District/Neighborhood: planning/street design for density, mix of compatible uses.

- City: planning for compact and viable sub-centers and affordable housing, intermodality movement, effective public transport systems.

- Regional: urban growth management, urban renewal, transport demand management, economic incentives/disincentives, regulations.

- National: coherent policy frameworks and investments.

An interesting example of integrated land use and transport planning for sustainable urban development is the Tianjin Eco-city planned jointly by the China Academy of Urban Planning \& Design, the Tianjin Urban Planning \& Design Institute, and a Singapore

Journal of Engineering Sciences, Assiut University, Faculty of Engineering, Vol. 41, No. 4, July, 2013,E-mail address: jes@aun.edu.eg 
Faez Saad Al-Shihri, Principles of sustainable development and their application in urban planning in saudi arabia, pp. 1703- 1727

planning team led by the Urban Redevelopment Authority [30]. The Eco-city is planned with the modular 'Eco-cell' concept. Each cell is about $400 \mathrm{~m}$ by $400 \mathrm{~m}$ large, generally accepted as a comfortable walking distance. Four Eco-cells make an Eco-neighborhood. Several Eco-neighborhoods come together to form an Eco-district.

\section{5. The contemporary global outlook}

Up-to-date, 'sustainable development' seems to have become a common planning agenda in many leading countries [31]. Global awareness and institutionalized recognition of environmental issues of greenhouse gas emissions, depleting natural resources and loss of biodiversity have evoked more sustainable land use practices [32]. In the US various states have adopted public policies to nudge local authorities towards reforming planning practices to halt urban sprawl [33]. In the UK, in order to make development sustainable, all levels of government have started to build citizen and stakeholder engagement into their policy-making processes. Countries like Canada, Holland and New Zealand have promulgated national legislation empowering local planning authorities to institutionalize key principles of sustainable development. [34], [35], [36], [37].

\section{6. Summary of sustainability principles: A sustainability assessment criteria}

To wrap-up this section, it is important to highlight the major sustainable development principles that we can extract from the review of literature above. Table 1 summarizes such principles, which should be incorporated in any country's policies, program and plans towards sustainable urban development. These principles are now among the major international best practices for sustainable development.

\section{Table 1.}

Summary of sustainable development principles extracted from the literature review

\begin{tabular}{|c|c|}
\hline Category & Principles \\
\hline \multirow{4}{*}{ Environmental } & Safeguard environmental quality - clean water, air and land \\
\hline & Protecting natural ecosystem \\
\hline & $\begin{array}{l}\text { Sustainable Land use planning to reduce sprawl and promote smart } \\
\text { growth }\end{array}$ \\
\hline & Reducing pollution and environmental degradation \\
\hline \multirow{4}{*}{ Economic } & $\begin{array}{l}\text { Conservation of natural resource: land, water, air, fauna, flora, } \\
\text { minerals, etc }\end{array}$ \\
\hline & Reus and recycle materials \\
\hline & $\begin{array}{l}\text { Expanding economic opportunities: green economy, use of local } \\
\text { resources }\end{array}$ \\
\hline & Sound economic policies and regulations \\
\hline \multirow{7}{*}{ Social } & Equity in resource distribution and employment \\
\hline & Sound Public transportation \\
\hline & Affordable housing to different income groups \\
\hline & $\begin{array}{l}\text { Sound Public participation: involving all stakeholders in decision } \\
\text { making }\end{array}$ \\
\hline & Improved Public health and safety \\
\hline & Quality education and public enlightenment about sustainability \\
\hline & Concern for the disadvantaged group: poor, handicap, minorities \\
\hline
\end{tabular}

Journal of Engineering Sciences, Assiut University, Faculty of Engineering, Vol. 41, No. 4, July, 2013,E-mail address: jes@aun.edu.eg 
Faez Saad Al-Shihri, Principles of sustainable development and their application in urban planning in saudi arabia, pp. 1703- 1727

Saudi Arabia in particular would reap substantial environmental and socio-economic benefits when such sustainability principles are incorporated into its national, regional and local development strategies. Thus the next section presents an assessment of whether these principles are integrated into Saudi National Development Plan, National Spatial Strategy, and General Environmental Law. The section starts with a general overview of sustainability in the kingdom within the context of rapid urbanization, booming economy and high level of energy and material consumption.

\section{The state of urban sustainability in Saudi Arabia}

Saudi Arabia is a country that is going through a process of rapid urbanization. The ratio of rural to urban population had reversed from 3:1 to 1:3 within a span of two decades (1970-1990). The population has grown at a high annual rate of 3.2 percent between 1974 and 2010. In the year 2010 population of the country was recorded at $27,136,977$ (including expatriate population), $88 \%$ of which live in urban areas now. The country is going through decades of high levels of public and private investment in industries, infrastructure and services. Population growth and urbanization are expected to continue at high rates.

Apparently, the parameters of planning and development of Saudi cities do not fulfill the conditions for sustainability. Some of the issues that threaten sustainability are [38] [39] [40] and [41]:

- Lack of coordination among the agencies, in planning, designing and implementing various projects .

- Expansion of urban boundaries, population growth and economic activity in some urban centers have increased environmental pressures, including; pollutant emissions from industrial facilities, increasing traffic within cities.

- In regard to Municipal services there are relative disparities in the standards between the urban centers and their surrounding villages .

- The harsh climate and lack of appropriate infrastructure is not conducive for walking.

- Inadequate Green spaces in the built up areas.

- Insufficient Green buildings which is a factor of high energy consumption.

- Lack of public awareness about the importance of sustainable development the importance reduction in the use of energy and other natural resources.(abdurhann- nine development)

However, there are signs of increasing realization of these problems and steps are being taken to come out of the existing lethargy in taking appropriate actions. The government is encouraging the development of eco-friendly buildings through the Saudi Green Buildings Forum, which held its conference at Riyadh in 2012. The government has funded research on developing alternative renewable energy technologies and has ambitious plans to switch to solar energy to meet a significant share of energy demand. A leading spokesman for the Kingdom has indicated that the nation has plans to become $100 \%$ powered by renewable and low-carbon forms of energy within decades [38]. A mass transit facility (LRT integrated with bus feeder service) has been initiated for the capital city Riyadh, with projects for Jeddah and Medina to follow. Relevant ministries are formulating plans and policies in the light of sustainability principles, although there are still weaknesses in the mechanism to translate the written statements into practical action. For example, Urban Growth Boundaries, which are intended to control urban sprawl, has become irrelevant because studies to determine the boundaries were far from being scientific or non-existent. [42], [43].

Journal of Engineering Sciences, Assiut University, Faculty of Engineering, Vol. 41, No. 4, July, 2013,E-mail address: jes@aun.edu.eg 
Faez Saad Al-Shihri, Principles of sustainable development and their application in urban planning in saudi arabia, pp. 1703- 1727

Public commitment on the issue of sustainability as provided in some of the government documents are as follows:

\section{1. Ninth national development plan}

The development of the Kingdom is guided by 5-year cycles of national development plans. The current one is the ninth in the sequence. The Eighth Development Plan (20052010) [41]recognized protecting the environment and promoting sustainable urban development as major issues to be addressed. The Eighth Plan also enunciated the future national vision in respect of urban growth management in the following terms: [39]

(1) "Transferring most powers from the central level to the regional and local of Amanats (principalities), Baladiats (municipalities) and Village Clusters".

(2) "Establishing the legal framework for spatial planning at the national, and regional levels through a comprehensive and standardized system of urban planning which clearly defines the powers and responsibilities of all concerned agencies, development directions and growth centers." - It is planned to introduce officially approved criteria for urban and rural planning ...... as well as towards directing land use and development in the context of preparing Structure Plans for cities and local Action Plans".

(3) Upgrading environmental health with defined and effective environmental criteria including protection of the air, water, soil, and fauna and flora, as well as protection of the built environment through proper planning of land use, noise control, recycling and treatment of urban waste, and waste water.

Based on the experience of the Eighth Development Plan, the Ninth Development Plan (2010-2015) has adopted a two-pronged strategy of "Protecting the Environment and Promoting Sustainable Urban Development". Towards this end the Ninth Plan reiterates that sustainability of its natural resources is one of the challenges for the nation, and accordingly highlights the strategic role of environmental management, focus attention on enforcement of the General Environmental Law and Rules for Implementation. [40].

The Plan adopts thirteen objectives as follows: [40]

1- To safeguard Islamic teachings and values, enhance national unity and security, guarantee human rights, maintain social stability, and consolidate the Arab and Islamic identity of the Kingdom.

2- To continue to develop the holy places, and improve the services provided to Hajj and Umrah performers to ensure performance of religious rites easily and conveniently.

3- To achieve sustainable economic and social development by accelerating the rate of economic growth and social welfare.

4- To achieve balanced development among regions of the Kingdom and enhance their role in social and economic development.

5- To enhance human development, expand the range of options open to individuals to enable them to acquire and use knowledge, skills and expertise, and provide appropriate healthcare services.

6- To raise the standard of living and improve the quality of life of all citizens.

7- To diversify the economic base horizontally and vertically, expand the absorptive and productive capacities of the national economy and enhance its competitiveness, and maximize the return on competitive advantages.

8- To move towards a knowledge-based economy and consolidate the basis of an information society. 
Faez Saad Al-Shihri, Principles of sustainable development and their application in urban planning in saudi arabia, pp. 1703- 1727

9- To enhance the role of the private sector in socioeconomic and environmental development and expand domains of private investments (domestic and foreign) and public-private partnerships.

10- To develop, conserve and ensure rational utilization of natural resources, particularly water, protect the environment and develop environmental systems within the context of sustainable development.

11- To continue socioeconomic and institutional reform, develop regulations aimed at raising efficiency and improving performance, work towards entrenching transparency and accountability, and support civil-society institutions in advancing their developmental activities.

12- To strengthen economic integration with Gulf Cooperation Council and Arab states and develop relations with Islamic and friendly countries.

13- To develop the sector of Small and Medium Enterprises to increase its contribution to GDP, and create frameworks for nurturing and organizing it.

The Ninth Plan has also identified Urban Development Zones for up to 2028 with a view to provide sustainable public services and utilities and thus attain an optimal size of cities and rural settlements in line with the National Spatial Development Strategy of 2001.

In order to protect the citizens of the country from any potential sources of pollution, the Council of Ministers through its Resolution \# 285, stipulated that the Ministry of Municipal \& Rural Affairs (MOMRA) shall not zone any land within oil, gas, and mining concession areas, and shall exclude "dangerous-to-inhabit" sites when preparing spatial development plans for cities and towns. [40]

Acknowledging the exploding and sprawling nature of Saudi cities, the Ninth Plan expresses the public commitment by stating that "ensuring sustainable development of cities requires addressing the multi-dimensional challenges through:[40]

- Adherence to long-term strategic plan as a national goal by prescribing Structure Planning as a mandatory style of planning for all municipal authorities.

- Inter-agency coordination to provide adequate public services in health, education, and infrastructure for water, sanitation, electricity, transport, communication through a comprehensive data-base.

- Strict application of urban boundary and land use regulations;

- Encouraging vertical development of cities within the capabilities of services such as water and sanitation;

- Providing an integrated, modern public transport system in major cities and suburbs;

- Developing radical solutions for vacant lands within cities, to ensure their optimal utilization; and

- Distributing economic opportunities and services facilities in a way that reduces horizontal expansion of large cities."

- Application of technologies for safe disposal of organic waste; enhancing technologies for recycling solid waste; ensuring wide spread coverage of the sanitation system; reducing pollutants in petroleum products; and reducing carbon pollutants emitted by vehicles and means of transport through strict traffic controls.

- Expanding participation of citizens through empowerment of elected members in the municipal councils.

\section{2. National spatial strategy}

The National Spatial Strategy (NSS) for Saudi Arabia was drawn up by the Ministry of Municipal and Rural Affairs in 2000 with technical assistance for the United Nations. The

Journal of Engineering Sciences, Assiut University, Faculty of Engineering, Vol. 41, No. 4, July, 2013,E-mail address: jes@aun.edu.eg 
Faez Saad Al-Shihri, Principles of sustainable development and their application in urban planning in saudi arabia, pp. 1703- 1727

focus of NSS is to ensure a balanced spatial development of the Kingdom. One of the challenges it attempts to address is "how to strike a balance between sustained urban development and protection of the environment [40]." The objectives of this strategy include the promotion of a more spatially balanced distribution of population through promoting a system of hierarchy of settlements with concomitant support for economic activities and services without hampering economic efficiency in the use of resources [44].

The NSS calls for policies such as ensuring the efficient utilization of infrastructure and public utilities already in place through compact urban development and improved urban fabric, and curtailing urban sprawl through the formulation of long-term Structure Plans for all cities in the kingdom based on strategic outlooks.

\section{3. General environmental law in the kingdom}

The General Environmental Law was declared by Royal Decree No. M/34, dt.28/7/1422 and was published in the official Gazette No. 3868, dt.24/8.1422 (09/11/2001). The General Environmental Law provides a general regulatory framework for the development and enforcement of environmental bye-laws and regulations. And the responsibility for this task is assigned to the Presidency of Meteorology \& Environmental Protection (PME).

The main concern for protection of the environment as identified by the government consists of the following sectors: (1) Agriculture (2) Industry (3) Transport (4) Man-made Environment (5) Natural Environment. Further, the objective functions in each sector were also spelled out clearly and comprehensively.

The General Environmental Law and its Rules for Implementation (GEL \& RI) were promulgated with the following objectives [46]:

- Preserve, protect and develop the environment and safeguard it from pollution.

- Protect public health from activities and acts that harm the environment.

- Conserve and develop natural resources and rationalize their use.

- Include environmental planning as an integral part of overall development planning in all industrial, agricultural, architectural and other areas.

- Raise awareness of environmental issues and strengthen individual and collective feelings of the sole and collective responsibility for preserving and improving the environment and encourage national voluntary efforts in this area.

The PME has authorized Meteorology \& Environmental Protection Administration (MEPA) to carry out the following tasks:

- Conduct environmental studies

- Prepare and publish reports on the results of such studies

- Prepare, publish and review (from time to time) relevant environmental standards

- Ensure that the environmental standards are strictly applied

- Prepare plans with other govt. agencies to deal with environmental catastrophes

- Promote general awareness for protecting the environment

- Work with other govt. agencies to deal with violations of environmental standards

General Environmental Law and its Rules for Implementation:

The Implementation Regulation to the General Environmental Law were issued by the Minister of Defense \& Aviation Resolution No. 1/1/4/5/1/924 dated 03/08/1424 (September 30, 2003) and published in the Official Gazette No.3964 dated 28/08/1424 (October 25, 2003) and came into

Journal of Engineering Sciences, Assiut University, Faculty of Engineering, Vol. 41, No. 4, July, 2013,E-mail address: jes@aun.edu.eg 
Faez Saad Al-Shihri, Principles of sustainable development and their application in urban planning in saudi arabia, pp. 1703- 1727

effect the same day. Under the Implementing Regulation any public authority that is responsible for issuing a license to projects must ask the applicant of the project that an Environmental Impact Assessment (EIA) is prepared during the feasibility study, without which licenses would not be issued. This is a landmark development in respect of legal support in favour of environmental protection.

\section{4. Public participation in the KSA}

In order to initiate the process of public participation at various levels of public decision making, the kingdom of Saudi Arabia has taken a pioneering step in 1993. A new governmental institution called the Shoura Council has been created by a Royal Decree No A/91 dated 27-8-1412 H. The Council is a consultative body set up on the basis of Quranic injunctions and the democratic practices of "consultation with companions" as exemplified by the Prophet of Islam (PBUH).

The Shoura Council has been empowered to perform the following functions [47]:

- Discuss the general plan for economic and social development stating its opinion.

- Study the rules and regulations, international treaties and agreements and concessions, giving its opinion thereon.

- Interpret Laws.

- Discuss annual reports prepared by the ministries and other government departments, giving its opinion thereon.

\section{5. The provincial system}

In order to decentralize administration and boost the process of development planning to all the provinces/regions, a new Provincial System of administration was introduced through a Royal Decree Royal Decree No A/91 dated 27-8-1412 H. At the same time the Provincial System is aimed at ensuring security as well as rights and freedom of citizens at all regional levels, and further down. Towards this end each Province is divided into a number of administrative districts called Muhafadha.

\section{6. Provincial council}

The Royal Decree of 1993 stipulated further that in every province a council called Provincial Council will be set up comprising of the Governor of the province, Heads of government departments in the province, and 10 knowledgeable, experienced, righteous and efficient domicile resident of the province.

The Provincial Council will propose any work of general benefit for the people of the province and thus will encourage participation of the people.

The Provincial Council will be entitled to study all matters, which will boost the standard of all services in the Province, especially to[47]:

- Identify the needs of the province and suggest their inclusion in the Five Year Development Plan of the country.

- Identify useful projects in accordance people's priority.

- Study the Master Directive Plans of the towns and villages of the province and follow up their implementation.

Journal of Engineering Sciences, Assiut University, Faculty of Engineering, Vol. 41, No. 4, July, 2013,E-mail address: jes@aun.edu.eg 
Faez Saad Al-Shihri, Principles of sustainable development and their application in urban planning in saudi arabia, pp. 1703-1727

- Follow up the implementation of the development plans and budget of the province and coordinate accordingly.

\section{7. Muhafadhah system}

In order to ensure sustained development through local participation the government has introduced the Muhafadhah system since 1993. The government also recognizes that comprehensive urban and/or rural development planning and implementation can best be carried out at the local levels because the constraints and opportunities in sustainable development can best be understood and appreciated at the local levels. With this end in view the government has taken steps to empower the municipalities and other units of local authorities to be independent in carrying out their responsibilities towards meeting the needs of the local population in a sustainable manner. The Muhafadha units are now expected to be capable and effective in respect of planning as well as implementation of sustainable development projects at local levels.

\section{8. Municipal councils}

In pursuance of the ideals of public participation, the government in the kingdom has endorsed the view that an effective role of local organization is to enable local people to influence decisions about planning and location of social facilities, roads and other infrastructure projects on the basis of the local knowledge, needs and priorities. With this orientation, the Council of Ministers (Resolution No, 224 dated 17/8/1424H) initiated a system of local citizens' participation in decision making by introducing Municipal Councils based on a system of election specifying that half of each municipal council members are to be elected. This action has ensured a means for fostering popular participation in decision making with a view to enhancing the level of services according to the felt-needs, desires and ambitions of citizens. In this way the base for sustainable development has been ensured. [48]. [49]:

The municipal elections provide an opportunity for all citizens to participate in the decision making through choosing those fellow citizens who are qualified and have experience as well as expertise, as their representative in the administration of municipal services. This is a window of opportunity to establish public participation as an institution for equitable and sustainable local development. It is hoped that this step will invoke as well as empower local authorities to embark on a mission to follow sustainability concepts, principles and actions meaningfully in all local development projects.

\section{Assessing the level of sustainability in Saudi development planning strategies}

This section attempts to sum up the review in the previous sections about the level of integrating sustainable development principles in the national policies in the kingdom of Saudi Arabia. Table 2 itemizes major sustainability principles extracted from literature and the extent of their application in the kingdom's National Development Plan (NDP), National Spatial Strategy (NSS) and General Environmental Law (GEL) as well as the extent to which these principles are embedded in these strategies and plans policies.

The assessment is based on subjective rating of the sustainable development principles. A low score indicates that the principle is present in just one of the three national plans/strategies. If a principle is found in two, then it is scored as moderate, while if it exists in all the three strategies then it is considered as highly incorporated at the national level.

Journal of Engineering Sciences, Assiut University, Faculty of Engineering, Vol. 41, No. 4, July, 2013,E-mail address: jes@aun.edu.eg 
Faez Saad Al-Shihri, Principles of sustainable development and their application in urban planning in saudi arabia, pp. 1703- 1727

\section{Table 2.}

Applications of Sustainable Development Principles in Saudi Development Planning strategies

\begin{tabular}{|c|c|c|c|}
\hline Category & Principle & Extent of Existence & $\begin{array}{c}\text { Level of } \\
\text { Application }\end{array}$ \\
\hline \multirow[t]{4}{*}{ Environmental } & Safeguard environmental quality & $\begin{array}{l}\text { High: enforcement of environmental } \\
\text { laws, balance development. }\end{array}$ & $\begin{array}{l}\text { GEL, } 9^{\text {th }} \text { NDP, } \\
\text { NSS }\end{array}$ \\
\hline & $\begin{array}{l}\text { Protecting and conserve natural } \\
\text { ecosystem }\end{array}$ & $\begin{array}{l}\text { High: efficient waste disposal } \\
\text { strategies and pollution prevention, } \\
\text { Conserve and develop natural } \\
\text { resources, balance development. }\end{array}$ & $\begin{array}{l}\text { GEL, } 9^{\text {th }} \text { NDP, } \\
\text { GEL }\end{array}$ \\
\hline & Sustainable land use planning & $\begin{array}{l}\text { High: Balance development, and } \\
\text { Conserve and develop natural } \\
\text { resources }\end{array}$ & $\begin{array}{l}9^{\text {th }} \text { NDP, NSS, } \\
\text { GEL }\end{array}$ \\
\hline & Promote smart growth & $\begin{array}{l}\text { High: urban growth boundary, } \\
\text { vertical development }\end{array}$ & $9^{\text {th }}$ NDP, NSS \\
\hline \multirow{5}{*}{ Economic } & Conservation of natural resource & $\begin{array}{l}\text { High: Conserve and develop natural } \\
\text { resources, balance development. }\end{array}$ & $\begin{array}{l}\text { GEL, } 9^{\text {th }} \text { NDP, } \\
\text { NSS }\end{array}$ \\
\hline & Reuse and recycle materials & $\begin{array}{l}\text { Moderate: Applying and enhancing } \\
\text { technologies for recycling. }\end{array}$ & GEL, $9^{\text {th }}$ NDP \\
\hline & \begin{tabular}{|l|} 
Expanding economic \\
opportunities
\end{tabular} & $\begin{array}{l}\text { Moderate: support and distribute } \\
\text { economic opportunities }\end{array}$ & $9^{\text {th }}$ NDP, NSS \\
\hline & $\begin{array}{l}\text { Sound economic policies and } \\
\text { regulations Balanced Spatial } \\
\text { Economy }\end{array}$ & High: Balanced Spatial Economy & $\begin{array}{l}\text { GEL, } 9^{\text {th }} \text { NDP, } \\
\text { NSS }\end{array}$ \\
\hline & $\begin{array}{l}\text { Sound economic policies and } \\
\text { regulations }\end{array}$ & $\begin{array}{l}\text { High: hierarchy of settlements and } \\
\text { employment }\end{array}$ & NSS, $9^{\text {th }}$ NDP \\
\hline \multirow{7}{*}{ Social } & $\begin{array}{l}\text { Equity in resource distribution and } \\
\text { employment }\end{array}$ & $\begin{array}{l}\text { High: Balanced spatial development } \\
\text { and resource distribution }\end{array}$ & $9^{\text {th }}$ NDP, NSS \\
\hline & Public transportation & $\begin{array}{l}\text { High: Light rail projects are } \\
\text { ongoing, providing an integrated } \\
\text { modern public transport system in } \\
\text { major cities and suburbs. }\end{array}$ & $\mathrm{NSS}, 9^{\text {th }} \mathrm{NDP}$ \\
\hline & Affordable housing & Moderate: public housing & NSS, $9^{\text {th }}$ NDP \\
\hline & Sound Public participation & $\begin{array}{l}\text { Moderate: Shoura, Provincial } \\
\text { councils, Expanding Participation } \\
\text { of citizens through empowerment of } \\
\text { elected member in the municipal } \\
\text { councils. }\end{array}$ & $9^{\text {th }}$ NDP, NSS. \\
\hline & Improved Public health and safety & $\begin{array}{l}\text { High: mining and industrial sites } \\
\text { located away from human } \\
\text { settlements, protect public health, } \\
\text { balance development. }\end{array}$ & $\begin{array}{l}\text { GEL, } 9^{\text {th }} \text { NDP, } \\
\text { NSS }\end{array}$ \\
\hline & $\begin{array}{l}\text { Quality education and public } \\
\text { enlightenment }\end{array}$ & $\begin{array}{l}\text { High: investment in education, raise } \\
\text { awareness of environmental issues, } \\
\text { Public participation. }\end{array}$ & $9^{\text {th }}$ NDP, GEL \\
\hline & $\begin{array}{l}\text { Concern for the disadvantaged } \\
\text { group }\end{array}$ & $\begin{array}{l}\text { High: balanced development, } \\
\text { Protecting the environment. }\end{array}$ & $\begin{array}{l}9^{\text {th }} \text { NDP, NSS, } \\
\text { GEL }\end{array}$ \\
\hline
\end{tabular}

Note: NSS (National Spatial Strategy); NDP (National Development Plan); GEL (General Environmental Law)

Journal of Engineering Sciences, Assiut University, Faculty of Engineering, Vol. 41, No. 4, July, 2013,E-mail address: jes@aun.edu.eg 

in saudi arabia, pp. 1703-1727

As table 2 indicated, the assessment of the level of incorporating the principles of sustainable development in Saudi Arabia shows that an effort is being made and the provision of these principles at the national level is high. The assessment indicates that most of the principles have been embedded into the national development plans, National Spatial Strategy and General Environmental Laws at either high or moderate levels. There is an existing framework that provides guidance to all sectors of urban development such as transportation, housing, basic services, facilities and infrastructure agencies, etc.

However, what remains is for all these sectors is to use this framework to develop program and implementation action policies to put these principles into practice. How to implement these principles that have been mentioned in the national policies should be their main priority task in achieving sustainable urban development in Saudi Arabia. The next section concludes on the way forward towards more sustainable urban development initiatives in Saudi Arabia.

\section{Conclusions}

The concepts, principles and strategies regarding sustainability in general and their application in the field of urban planning in particular are still in a flux across the world. From the limited purview of this work it is clear that information in respect of concept, principles, strategies, and practical actions aimed at planning for sustainability abound. From the array of available written materials meaningful principles can be culled and action plans appropriate for each individual situation can be formulated. For the sake of clarity, actions can be conceived and articulated into three areas: corrective, promotive, and preventive. Obviously, for each area supportive legislation would be indispensable. Without due legislation, actions would remain stillborn.

The trend and pattern of urban development in Saudi Arabia is a cause for serious concern in terms of sustainability. Sprawling pattern of urban development, undeterminative settlement policy, unimaginative land use, increasing pollution due to unregulated industrial activities and traffic, proliferation of motor vehicles, unplanned and inadequate public transport system, lack of green space, are all serious issues that threaten the sustainability of urban development. However, studies similar to this provide an opportunity for the decision makers to another thought on whether the kingdom should continue on this path or pause for a moment and review its existing strategies to address these serious sustainability challenges.

The prevailing scene and the emerging scenario challenge the professionals in the country to pay urgent attention to sustainability principles. The starting point for the urban planners in the country is to start at the planning process itself. Fortunately, Structure Planning has been mandated by the Ministry of Municipal \& Rural Affairs (MOMRA) asprinciples have been embedded in the Structure Planning process. But it is up to the planners to thoughtfully articulate the principles in to applicable action plans and programs supported with the force of bye-laws.

It is clear through the limited review of vast literature that planning for sustainability requires a common understanding of the concept as well as that of the principles that entail, amongst all cadres of professionals involved at various levels of planning for development in the country. In this respect the national development planners seem to have adequately internalized the issue of sustainability in national development planning to the

Journal of Engineering Sciences, Assiut University, Faculty of Engineering, Vol. 41, No. 4, July, 2013,E-mail address: jes@aun.edu.eg 
Faez Saad Al-Shihri, Principles of sustainable development and their application in urban planning in saudi arabia, pp. 1703-1727

extent that the Eighth Five-year Plan (2005-2010) has invoked long-term planning not only for cities and towns but also for the surrounding larger regions. Starting with the Eighth Five year Plan the kingdom has embarked on a long term perspective plan entitled Vision 2020.

The Structure Planning process as mandated by MOMRA empowers the local authorities to plan for the larger 'city regions' rather than the confines of the municipal boundaries. This principle, if practiced properly will ensure sustainability of not only the urban centers but that of urban regions. Obviously, the present Muhafadhah system rightfully allows for the Structure Plans to be prepared covering the wider areas indicated here. For the sake of sustainability, therefore, Muhafadhah level planning should be adopted. This would also ensure territorial comprehensiveness. This is a clear opportunity for the local authority planners to dove-tail their respective area plans (Structure Plans) into the Vision 2020.

The government has shown its commitment to environmental protection by promulgating the General Environmental Law in the Kingdom as well as by creating the necessary administrative organ, the Presidency of Meteorology \& Environmental Protection (PME). It is now obligatory for the local authorities to work together with the PME to work out appropriate and effective byelaws towards ensuring sustainable urban environment in respect of land resource conservation, conservation of the flora and fauna, conservation of wetlands and coastal areas, water conservation, pollution control of both air and water, noise pollution, waste disposal, and so on. Such bye-laws formulated by joint efforts must be supported by 'police power' for the sake of easy implementation. The output of such joint efforts i.e. the bye-laws should form the basis of preparing action plans for any sectoral vis-à-vis spatial development plans.

This review makes it abundantly clear that public participation is a pre-requisite for truly sustainable development. In the movement for sustainable development the on-going slogan is 'think globally, act locally'. To 'act locally' implies action at two levels: public and private/individual. The public level participation has been facilitated by the government empowering the municipalities to form Municipal Councils inclusive of elected public representatives. This is a mile stone social development in respect of citizen participation in municipal affairs.

However, the other dimension of public participation is cooperation and participation by individual citizens based on their own understanding and realization of the need to saving non-renewable energy (petroleum, natural gas), saving water, recycling waste, greening the micro environment (green wall, green roof, green yard) etc. This, of course, would require education, both formal and informal, and voluntary change of life style. To this end, continuing education of professionals and tertiary education of future professionals is imperative. Equally important is informal education of the citizens at large, which might remain as the last obstacle in achieving sustainable environment and sustainable society, the cornerstone of sustainable civilization.

Finally let us come back to the main aim of this article that attempts to assess the application sustainability in Saudi Arabia. What can we say on the status of sustainability in the Kingdom? There is no single answer. But we can conclude that Saudi Arabia has incorporated most of the major sustainable development principles that have been extracted from literature reviewed. Implementing these principles at regional, urban and

Journal of Engineering Sciences, Assiut University, Faculty of Engineering, Vol. 41, No. 4, July, 2013,E-mail address: jes@aun.edu.eg 
Faez Saad Al-Shihri, Principles of sustainable development and their application in urban planning in saudi arabia, pp. 1703- 1727

local levels by various urban development actors and sectors would go a long way in achieving sustainable urban development.

These actors and agencies should prepare programs and projects to successfully implement these sustainable development principles at various social, economic and environmental sectors such as housing, transportation and infrastructure, urban services, industrial and commercial land uses, etc. It is hoped that concerted efforts at national, regional and local levels by the government and other stakeholders like the private sector and the academia would be taken to move the country forward towards achieving more sustainable development that will benefit the present and future generations.

\section{Notes}

1- This town (Tama New Town, Japan) was initially developed in the 1960's as a so-called dormitory town, whose residents commute to Tokyo for work. The expansive, low priority development site with a hilly topography is an epitome of unsustainable residential development. The community was experiencing low occupancy rates at least partly due to changing demographic structure and problems with mobility in the town. A research by the School of Architecture and Planning of the Massachusetts Institute of Technology attempted to envision, program and design directions for a prototypical sustainable community for the period 2030-2050. The researchers identified the 10 principles for sustainable development:

- $100 \%$ energy production on site: Energy self-sufficiency / zero energy importation.

- Development of zero-emission mobility system: All electric systems within site/ on demand access integrated with other low energy solutions.

- $100 \%$ grey water reuse: All storms and housing grey water to be re-used.

- Adaptable community housing units: Housing units to be adaptive to change over lifetime and reconfigurable.

- Progressive reduction of total site carbon profile / carbon footprint per person.

- $50 \%$ of available open space used to support local community-based agriculture and industry, supporting local community employment initiatives.

- $60 \%$ reduction in energy use: use of passive heating and cooling climate strategies, conservation and behavioral change.

- Use of ecological construction systems: low carbon material systems / zero emission construction/ adaptive re-use systems.

- Conservation of habitat and landscape continuity: enhancing the local and regional eco-system in and beyond the site.

- Building and sustaining the local economic base of the community 'green economics' - industry, services, connectivity to hub to Tokyo.

2- An interesting example of integrated land use and transport planning for sustainable urban development is the Tianjin Eco-city planned jointly by the China Academy of Urban Planning \& Design, the Tianjin Urban Planning \& Design Institute, and a Singapore planning team led by the Urban Redevelopment Authority [30]. The Eco-city is planned with the modular 'Eco-cell' concept (Figure 4). Each cell is about $400 \mathrm{~m}$ by $400 \mathrm{~m}$ large, generally accepted as a comfortable walking distance. Four Eco-cells make an Eco-neighborhood. Several Eco-neighborhoods come together to form an Ecodistrict.

Journal of Engineering Sciences, Assiut University, Faculty of Engineering, Vol. 41, No. 4, July, 2013,E-mail address: jes@aun.edu.eg 
Faez Saad Al-Shihri, Principles of sustainable development and their application in urban planning in saudi arabia, pp. 1703-1727

3- The Eco-city has a compact plan, with a good mix of land uses and is based on TransitOriented Development (TOD) principles. Each district is planned with amenities and jobs located close by. Local and centralized facilities are provided to serve the needs of residents in each neighborhood. Each district is served by urban centers. Business Parks are located close to residential areas to curtail transport demand.

4- A key feature of the transport planning of Eco-city is the aim to increase trips via public transport and non-motorized modes of transport such as via bicycles and walking. To achieve this, non-motorized and motorized networks will be separated to minimize conflict between pedestrians, cyclists and vehicles, with priority given to pedestrians and non-motorized transport, as well as public transport.

\section{References}

[1] Brundtland, H., 1987, Our Common Future: Report of the World Commission on Environment and Development. Oxford.

[2] http://www.johannesburgsummit.org/html/documents/summit_docs/131302_wssd_report_reissued. pdf

[3] Seijdel, R., Bots, P. and Dullemond, A. (2006) Nova Terra: Connected Cities, June 2006, pp. 23-30.

[4] Boyko, Christopher T., Cooper, Rachel, Davey, Davey, Caroline L. and Wootton, Andrew B. (2006) "Addressing sustainability early in the urban design process," Management of Envronmental Quality: An International Journal, Vol. 17, No. 6, pp. 689-706.

[5] Daly, H.E. (1991) Steady State Economics. Island press, Washington D.C., cited in Minken et al. (2003).

[6] Chichilnisky, G. (1996) "An axiomatic approach to sustainable development" Social Choice and Welfare Vol. 13, No. 2, pp. 231-257, cited in Minken et al. (2003).

[7] Heal, G. (2000) Valuing the Future. Economic Theory and Sustainability Economics for sustainable earth series, Columbia University Press, New York, cited in Minken et al. (2003).

[8] Minken, H., Jonsson, D., Shepherd, S., Järvi, T., May, T., Page, M., Pearman, A., Pfaffenbichler, P., Timms, P. and Vold, A. (2003) "Developing Sustainable Land Use and Transport Strategies: A Methodological Guidebook", Institute of Transport Economics, Oslo.

[9] Silvius, A.J.G. andSchipper, R. (2010) “A Maturity Model for Integrating Sustainability in Projects and Project Management," paper presented at the IPMA World Congress, Istanbul, 1-3 November, 2010.

[10] Elkington, J. (1997), Cannibals with Forks: the Triple Bottom Line of 21st Century Business, Capstone Publishing, Oxford, cited in Silvius and Schipper (2010).

[11] The US, the President's Council for Sustainable Developmenthttp://clinton5.nara.gov/PCSD/

[12] APA (2000); Policy Guide Adopted by American Planning Association Chapter Delegate Assembly, April 16, New York.), American Planning Association,

[13] Wheeler, S. (2004) Planning Sustainable and Livable Cities, Routledge, New York.

[14] Smith, M.K. (2008) "Sustainable communities and neighbourhoods. Theory, policy and practice"; the encyclopaedia of informal education,

URL: http://www.infed.org/communities/sustainable_communities.htm, accessed on 12 June, 2012.

[15] UN (2012), Report on the United Nations Conference on Sustainable Development,United Nations, New York.

[16] Smith, M.K. (2008) "Sustainable communities and neighbourhoods. Theory, policy and practice," the encyclopaedia of informal education,

URL: http://www.infed.org/communities/sustainable_communities.htm, accessed on 12 June, 2012.

[17] Boyko, Christopher T., Cooper, Rachel, Davey, Davey, Caroline L. Washington, DC.

[18] Andrew Wootton, Andrew B. (2006) "Addressing sustainability early in the urban design process," Management of Environmental Quality: An International Journal, Vol. 17, No. 6, pp. 689-706.

[19] UN (2009), Human Settlements Program; Planning Sustainable Cities: Global Report on Human Settlements 2009, Earthscan, London.

Journal of Engineering Sciences, Assiut University, Faculty of Engineering, Vol. 41, No. 4, July, 2013,E-mail address: jes@aun.edu.eg 
Faez Saad Al-Shihri, Principles of sustainable development and their application in urban planning in saudi arabia, pp. 1703- 1727

[20] Amado, M.P., Santos, C.V., Moura, E.B. and Silva, V.G. (2009) 'Public Participation in Sustainable Urban Planning,' World Academy of Science: Science and Engineering, Vol. 53, pp. 597-603.

[21] Rydin, Y. (2011), The Purpose of Planning: Creating Sustainable Towns and Cities, Policy Press, Bristol.

[22] Minken, H., Jonsson, D., Shepherd, S., Järvi, T., May, T., Page, M., Pearman, A., Pfaffenbichler, P., Timms, P. and Vold, A. (2003) "Developing Sustainable Land Use and Transport Strategies: A Methodological Guidebook", Institute of Transport Economics, Oslo.

[23] http://www.involve.org.uk/evaluation/

[24] Calthorpe, P. and Fulton, W., 2001. The Regional City: Planning for the End of Sprawl. Island Press, Washington, D.C., USA

[25] CNU (2001) "Charter of the New Urbanism", Congress for the New Urbanism (CNU), URL: http://www.cnu.org/sites/www.cnu.org/files/charter_english1.pdf, accessed on 25 October, 2012.

[26] CaGBC (2012) "What is Smart Growth?" Canada Green Building Council (CaGBC), URL: http://www.cagbc.org/Content/NavigationMenu/Programs/SmartGrowth/default.htm accessed on 25 October, 2012.

[27] Ziegler, E.H. (2009) "The case for megapolitan growth management in the twenty-first century: Regional urban planning and sustainable development in the USA," International Journal of Law in the Built Environment, Vol. 1, No. 2, pp. 105-129.

[28] Scott, A. and Ben-Joseph, E. (2011) ReNew Town: Adaptive Urbanism and the Design of the Low Carbon Community, Routledge, Oxford.

[29] Hadenius, A. and Ericson, J. (2006) "Sustainable Urban Transport: Final Report from the European project Trendsetter", Environmental and Health Protection Agency, City of Stockholm, Stockholm.

[30] Schlosser, C. (undated) "Effective strategies for sustainable urban transport: Policy options for national and local governments" UN-Habitat. Document accessed on 24 October, 2012 http://www.unhabitat.org/downloads/docs/8858 98181_1_UNHa\%20overview\%207oct10.pdf.

[31] Singapore Government (2012) 'Tianjin Ecocity: A Model for Sustainable Development', URL: http://www.tianjinecocity.gov.sg/bg masterplan.htm, accessed on 25 October, 2012.

[32] Beatley, Timothy \& Kristi Manning. 1998. The ecology of place: Planning for environment, economy and community. Washington, DC: island.

[33] Vitousek, P.M., Mooney, H.A., Lubchenco, J., Melillo, J.M., 1997. Human domination of earth's ecosystems. Science 277, 494-499.

[34] Krizek, Kevin and Joe Power: A Planners Guide to Sustainable Development, Planners Advisory Service Report No.467, American Planning Association, December, 1996.

[35] Berke, P.R., J. Dixon, and N. Ericksen. 1997. Coercive and cooperative intergovernmental mandates: a comparative analysis of Florida and New Zealand environmental plans. Environment and Planning B: Planning and Design. 24: 451-468.

[36] Mega,Voula. 1996. Our city, our future: Towards sustainable development in European cities. Environment and Urbanization 8, 1: 133-54.

[37] Roseland, M. (1992). Towards sustainable communities. Ottawa, Ontario:National round table on the environment and the economy.

[38] Susilawati, C. and Al-Surf, M (2011) "Challenges Facing Sustainable Housing in Saudi Arabia: A current study showing the level of public awareness" paper presented at the 17th Pacific Rim Real Estate Society Conference, Gold Coast, Australia, 16-19 January 2011.

[39] MEP (2005), The Eighth Five-year Development Plan,1427-1431H,Ministry of Economy \& Planning, Riyadh, KSA,

URL: http://www.planning.gov.sa/home/Home/English/8Plan/ch.30.htm, accessed on April 10, 2013.

[40] MEP (2010) The Ninth Five-year Development Plan: 1431-1435H, Ministry of Economy and Planning, (MEP), Riyadh, KSA. Ch.32 (PP627-630)

[41] Al-sayl, A. (2013), A strategy to transform Al-Khubar into a green city, unpublished graduation project report, college of architecture \& planning, university of dammam. Saudi Arabia.

[42] The Guardian (2012) "Saudi Arabia reveals plans to be powered entirely by renewable energy" URL: http://www.guardian.co.uk/environment/2012/oct/19/saudi-arabia-renewable-energy-oil, accessed on 27 October, 2012.

Journal of Engineering Sciences, Assiut University, Faculty of Engineering, Vol. 41, No. 4, July, 2013,E-mail address: jes@aun.edu.eg 
Faez Saad Al-Shihri, Principles of sustainable development and their application in urban planning in saudi arabia, pp. 1703- 1727

[43] Global Mass Transit Report (2011) "Public transport in Saudi Arabia: Embracing comprehensive mobility"; URL: http://www.globalmasstransit.net/archive.php?id=6463, accessed on 27 October, 2012

[44] MOMRA (2001) National Spatial Strategy: $1422 \mathrm{H}-2001$ AD Ministry of Municipal and Rural Affairs (MOMRA), Kingdom of Saudi Arabia, Riyadh.

[45] Al-Jarallah, M. (2001) Statement by the Minister of Municipal and Rural Affairs of the Kingdom of Saudi Arabia at the special session of the United Nations General Assembly for an overview and appraisal of the implementation of the outcome of the United Nations Conference on Human Settlements (Habitat II), 6-8 June, 2001, New York.

[46] PME, (2001) "General Environmental Law and Rules for Implementation" Presidency of Meteorology and Environment (PME), Kingdom of Saudi Arabia, URL: http://www.pme.gov.sa/en/env regul.asp accessed on 27 October, 2012.

[47] http://www.shura.gov.sa/wps/wcm/connect/ShuraEn/internet/Home/

[48] https://www.moi.gov.sa

[49] http://majales.momra.gov.sa

\section{مبادئ التنمية المستدامة ومدى تطبيقها في التخطيط للتنمية الحضرية بالمملكة العربية الستودية في الفية}

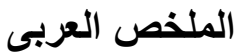

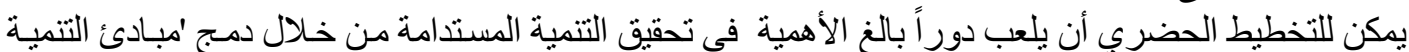

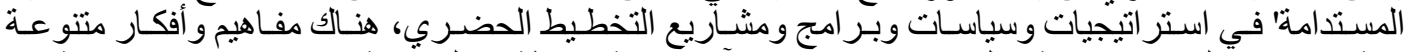

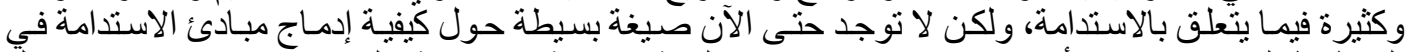

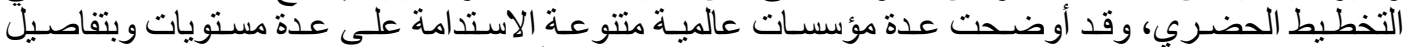

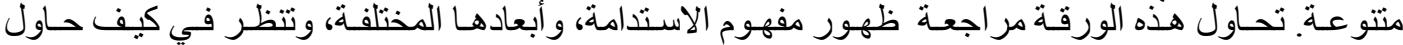

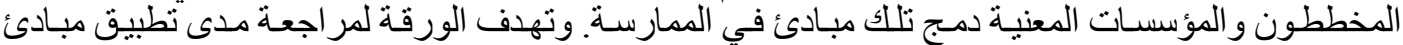

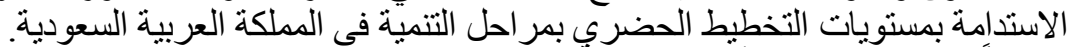

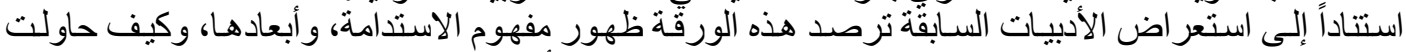

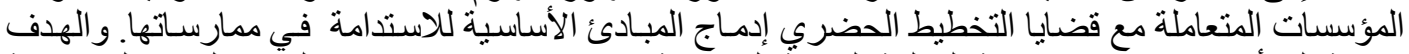

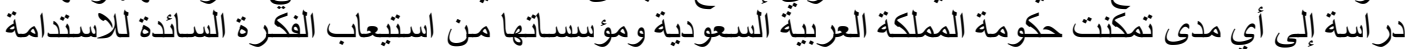

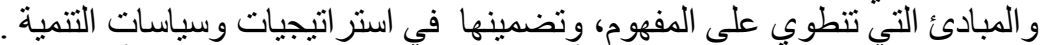

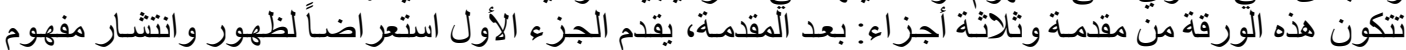

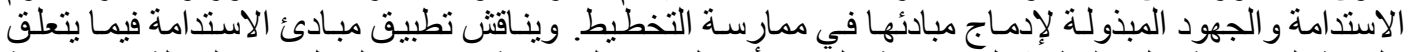

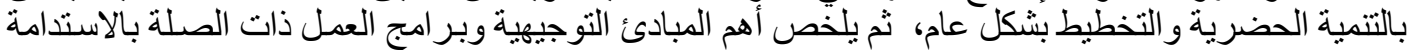

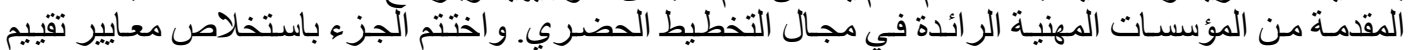

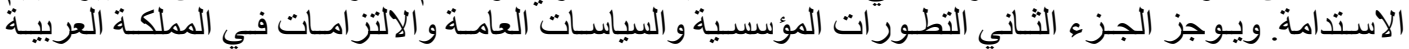

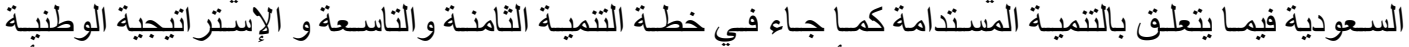

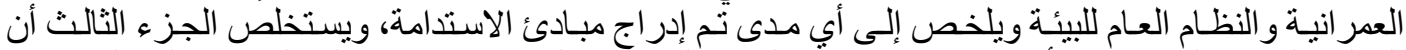

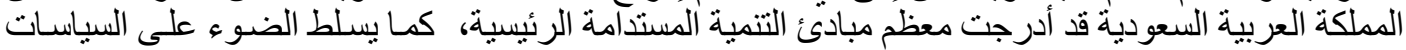

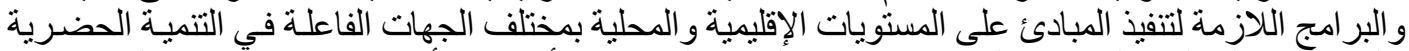

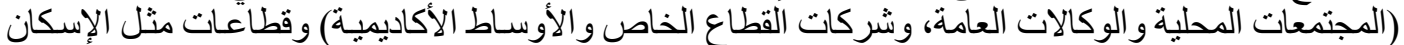

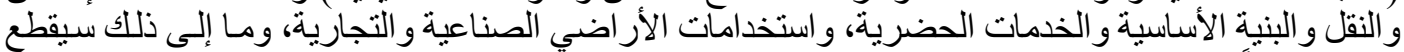

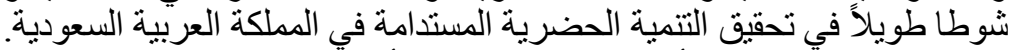

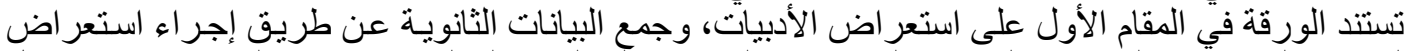

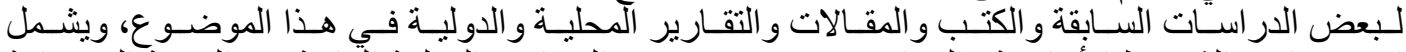

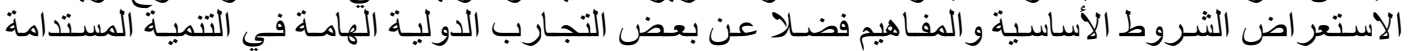

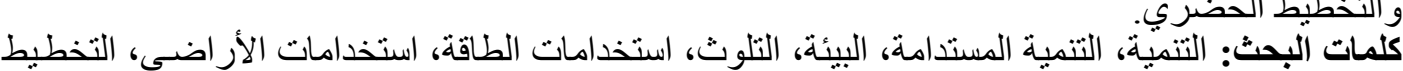

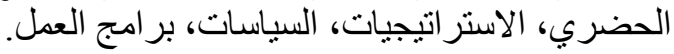

Journal of Engineering Sciences, Assiut University, Faculty of Engineering, Vol. 41, No. 4, July, 2013,E-mail address: jes@aun.edu.eg 